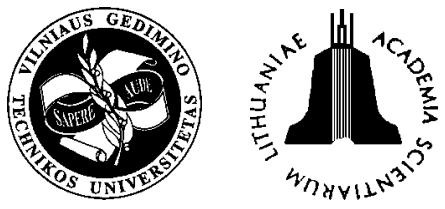

ISSN 1648-4142 TRANSPORT

http:/www.vtu.lt/english/editions

TRANSPORT - 2004, Vol XIX, No 1, 3-8

\title{
ANALYSIS AND FORECAST OF THE DYNAMICS OF PASSENGER TRANSPORTATION BY PUBLIC LAND TRANSPORT
}

\author{
Jonas Butkevičius ${ }^{1}$, Mindaugas Mazūra², Vladas Ivankovas ${ }^{3}$, Skirmantas Mazūra ${ }^{4}$ \\ Dept of Transport Management, Vilnius Gediminas Technical University, \\ Plytines 27, LT-10105 Vilnius-16, Lithuania \\ Received 2003-12-17; accepted 2004-01-15
}

\begin{abstract}
In the presented paper the dynamics of passenger haulage by public transport is considered and a forecast is made.

In Lithuania the total volume of passenger transportation by public land transport considerably decreased in the period from 1992 to 2001. In fact, the number of passengers carried by these transport facilities decreased by 3.1 times. The most considerable decrease was found on the local (suburban) bus routes and on international railway routes - by 5.6 and by 5 times, respectively. Long-distance transportation by bus which decreased only by 1.6 times was the least affected. The paper aims to identify major causes of transportation decrease common to road and railway transport (i.e. considerable growth of tariffs, fast growth of the number of personal motor cars, wear of transport facilities, lack of comfort, low prestige of public transport, etc.). The emphasis is placed on making a forecast of passenger traffic by using a multiple regression. The calculations show that the national income is the most reliable parameter for making forecasts of land transport development compared to a number of others, including national income, a gross national product, average monthly payment, household income and expenditures, national wealth, the index of production and users' cost, and the variation of consumer goods and services. The forecasts show that passenger haulage by public transport will reach $575 \mathrm{~m}$ by 2010 , while by 2015 it will grow up to $893 \mathrm{~m}$. This means that transportation will increase by 1,6 times and 2,3 times, respectively, compared to passenger haulage in 2001. However, passenger transportation in 2015 will not achieve the volume found in 2001.

The data of the considered forecast were used developing the strategies of national road and railway transport development.

Keywords: public transport; road and railway transport; forecast; multiple regression analysis; long-distance and international transportation; regression equation.
\end{abstract}

\section{Introduction}

The analysis and forecast of transportation is one of the goals of National Programme of Transport Development. This is a complicated problem which has not however, been discussed much in the literature of our country and abroad. Not a few authors handled the problems of planning but the works on forecasting in transport are scarce. Therefore, the emphasis should be placed on forecasts as a relevant problem of passenger transportation development.

The use of two-dimensional regression and correlation analysis is not sufficient for making forecasts $[1,2]$. The criteria evaluating transport development should be considered in a wider context of various economic indices and trends of economical and transport development

\footnotetext{
1 E-mail: vladas@ti.vtu.lt

2 E-mail:minmaz@ti.vtu.lt

3 E-mail: vladas@ti.vtu.lt

${ }^{4}$ E-mail: skirma@centras.lt
}

in Lithuania [3-8]. General indices characterizing economic development are gross national product, national income, production capacities, etc. Therefore, in order to obtain regression equations to be used in describing the economic aspects of transport development (i.e. volumes of freight and passenger transportation, turnover of freight and passengers, etc. relating both to a transport system as a whole and for its particular areas) multiple regression and correlation analysis should be used. The tests performed have shown that it is hardly expedient to use regression equations with multiple parameters, because the resulting equations (especially for a small number of observations) will show random deviations rather than a major trend of development of a particular process.

\section{Analysis of passenger transportation dynamics}

The total number of passengers transported by public land transport in 1992-2001 decreased by 3,1 times from $1103,2 \mathrm{~m}$ to $354,1 \mathrm{~m}$ people (Fig 1). 


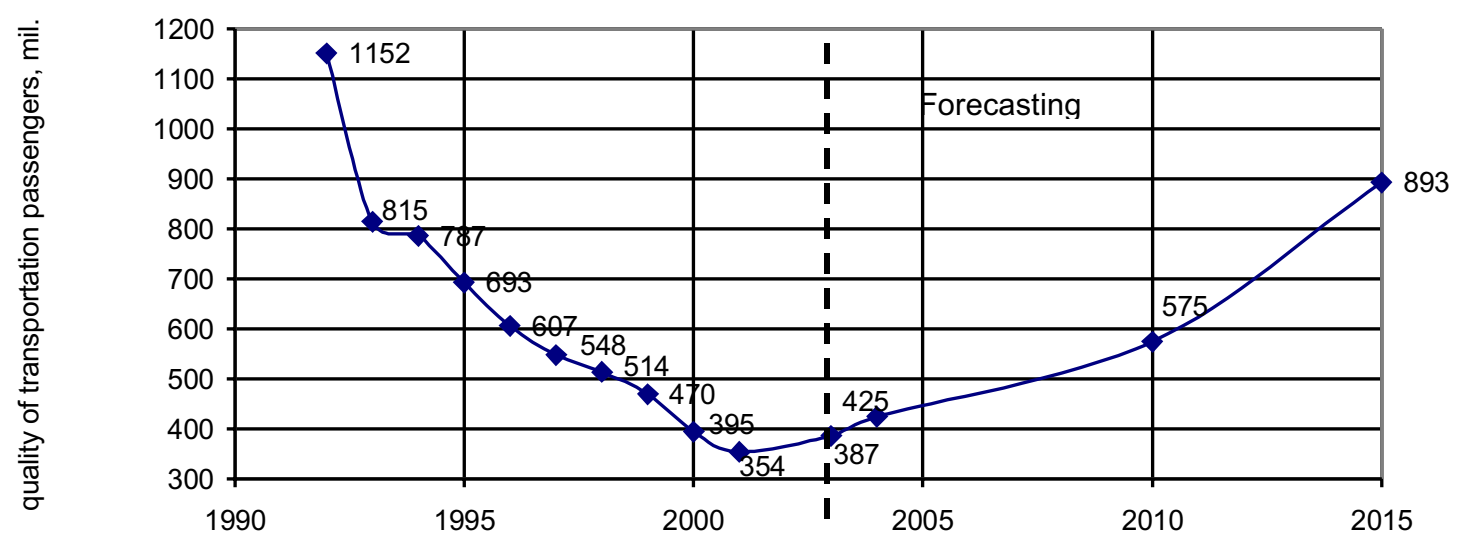

Fig 1. Transportation by land transport (in block)

Passenger transportation on local (urban) routes. The most widely used transport facilities in Lithuanian towns are buses now used in 31 city, though in 1998 they were available in 48 towns. In the period from 1992 to 2001 the number of passengers carried by bus on local (urban) routes was constantly decreasing, and the total number of routes decreased from 275 to 255 bus routes. The total length of bus routes decreased from 3200 to $2900 \mathrm{~km}$, while the number of the transported passengers dropped from 474,7 to $141,1 \mathrm{~m}$ people, i.e. it decreased by as much as 3,2 times (Fig 2).

The cost of $1 \mathrm{~km}$ bus run on an urban bus route is constantly increasing. For example, in 1998 in Kaunas it was 2,20 Lt, while in 1999 it reached 2,32 Lt, and in 2000 the cost increased to $2,80 \mathrm{Lt}$.

Passenger transportation on local (urban) trolleybus routes also considerably decreased - in 1992-2001 the number of passengers dropped from $326,1 \mathrm{~m}$ to 164,3 m people (Fig 2).

Passenger transportation on local (suburban) bus routes in the same period decreased, with the number of suburban bus routes dropping from 1171 to 1151 , their route length decreasing from 44,2 thous. to 40,8 thous. $\mathrm{km}$ and the number of the transported passengers decreesing from $123,9 \mathrm{~m}$ to $22,5 \mathrm{~m}$, i.e. as much as by 5,6 times.

Various changes took place in 1992-2001 in passenger transportation by publicly used buses on longdistance routes. For example, the number of long-distance routes was constantly decreasing in 1992-1996 (it dropped from 435 to 389 ), the total route length also decreased (from 66,8 thous. to 61,0 thous. $\mathrm{km}$ ), while the total number of the transported passengers dropped from $43,4 \mathrm{~m}$ to $20,6 \mathrm{~m}$ people, i.e. decreased by 2,1 times. In 1997-2001, the number of routes slightly decreased from 400 to 389 routes, while their total length dropped from 65,6 thous. to 64,8 thous. $\mathrm{km}$, and the number of transported passengers decreased from $18,7 \mathrm{~m}$ to $11,7 \mathrm{~m}$ people, i.e. by 1,6 times (Fig 2).

In 1992-2001, the total length of international bus routes considerably increased - from 9,9 thous. to 13,8 thous. $\mathrm{km}$, though the number of passengers transported on international routes dropped from $4,3 \mathrm{~m}$ to $0,98 \mathrm{~m}$, i.e. decreased by 4,3 times (Fig 3). An increase was observed only in an average distance travelled by

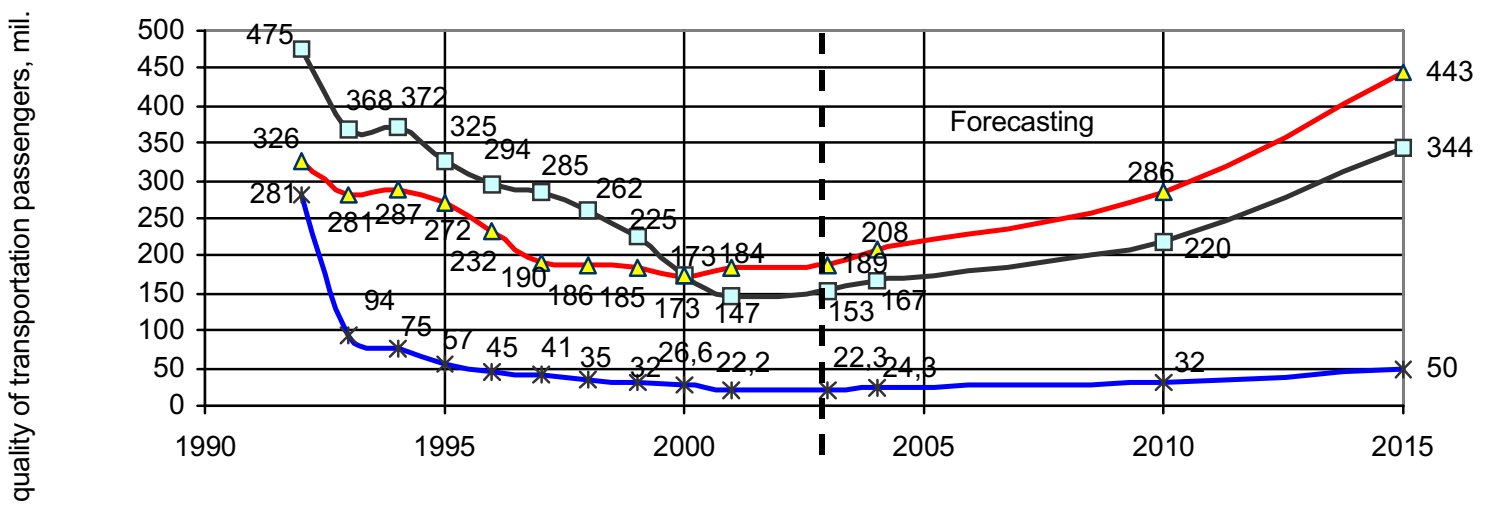

$-\square$ cities transportation by bus $\quad \triangle$ cities transportation by trolleybus $\rightarrow$ suburban transportation by bus

Fig 2. Transportation of passengers by city transport (bus, trolleybus) and suburban transportation by bus 

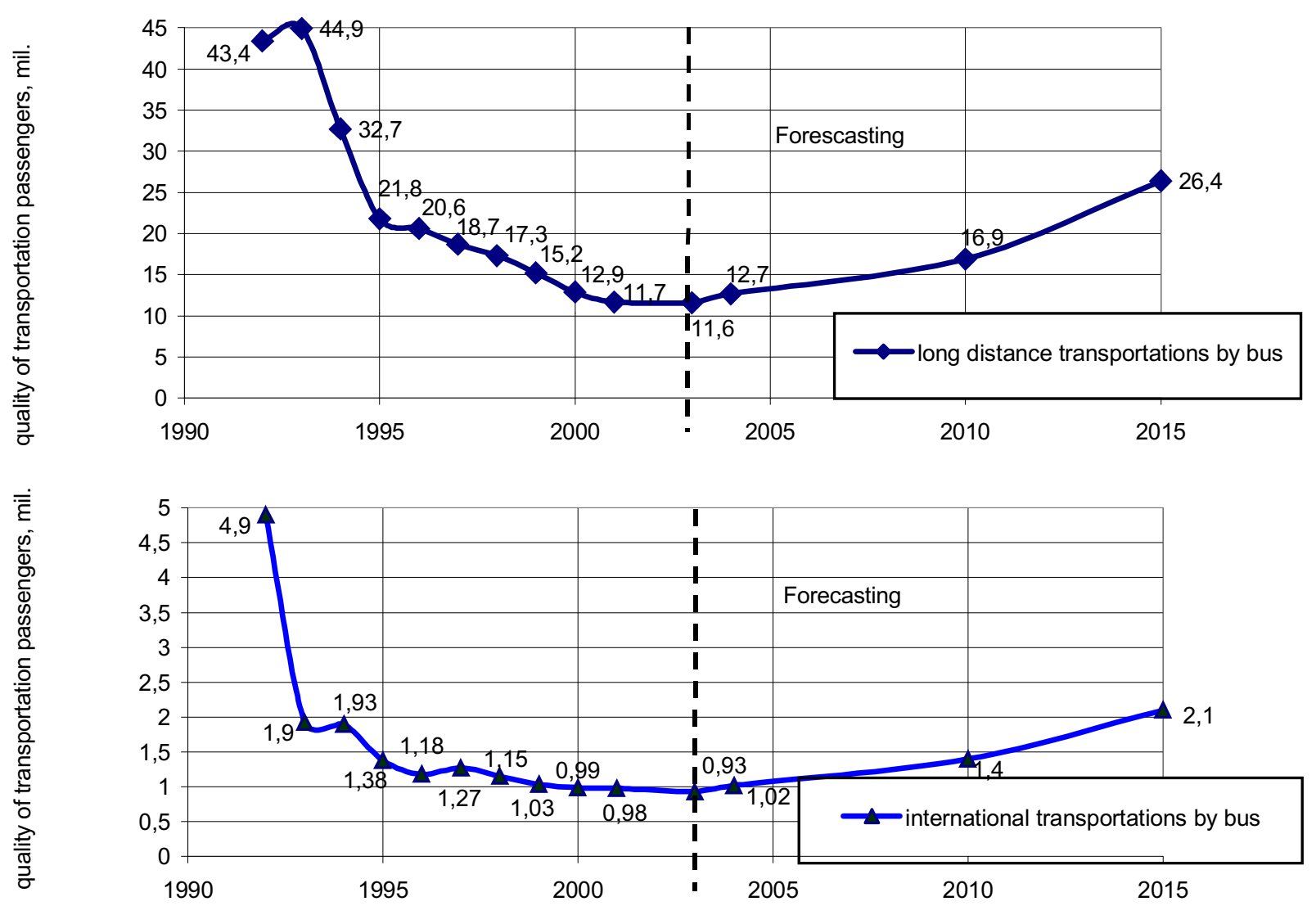

Fig 3. Long distance and international passenger transportation by bus

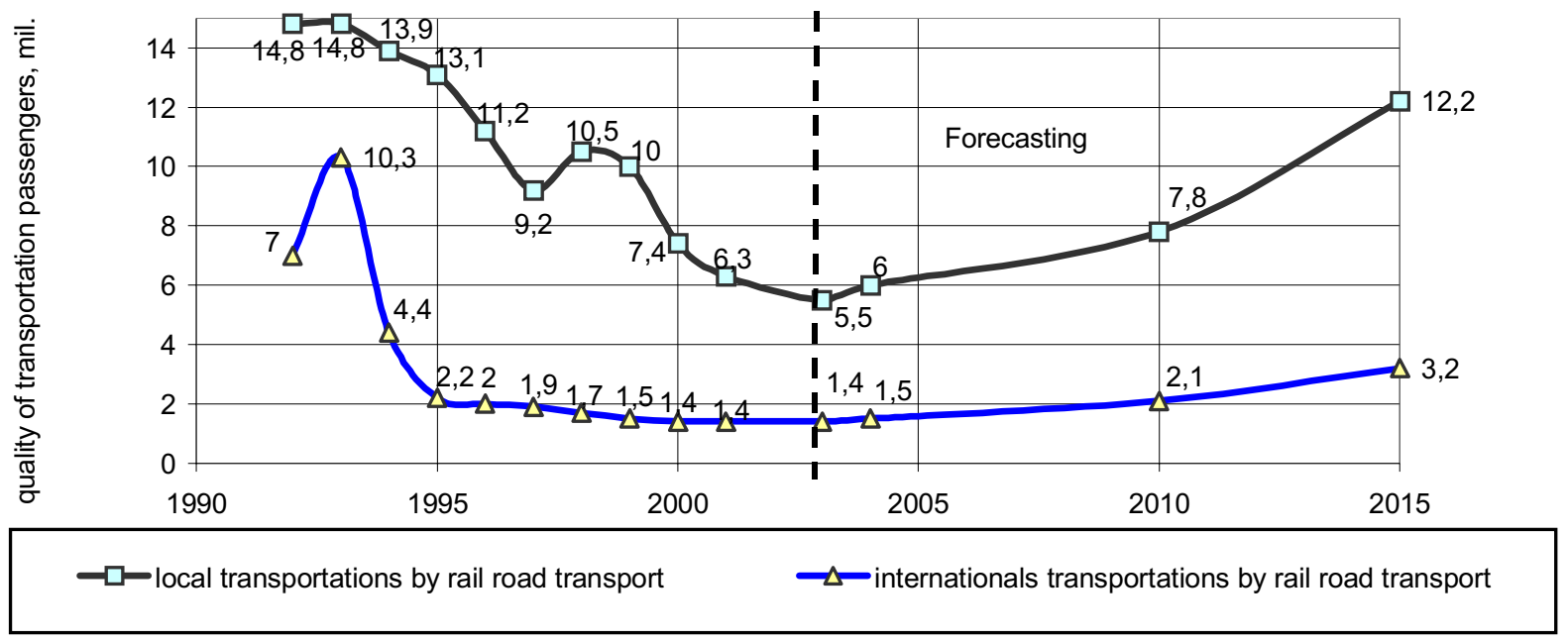

Fig 4. Passenger transportation by local and international rail road transport

passengers, which grew from $332 \mathrm{~km}$ to $1318 \mathrm{~km}$.

The total number of passengers carried by railway on the local (national) routes in 1992-2001 dropped from $14,8 \mathrm{~m}$ to $6,3 \mathrm{~m}$ people, decreasing by 2,3 times, while on international routes it dropped from $7,0 \mathrm{~m}$ to $1,4 \mathrm{~m}$ people, i.e. decreased by 5 times (Fig 4).
The investigation has shown [9] that the main causes of a considerable decrease in the number of passengers using road and railway transport are as follows:

1) a considerable rise in tariffs. For example, in 1994-1999 the tariffs on the local railway routes increased from 2,5 to $10,0 \mathrm{ct} / \mathrm{km}$, i.e. grew by 4 times; 
2) fast growth of the number of personal cars, which grew from 129 to 304 thous. cars, i.e. by 2,4 times in 1991-2001;

3) the number of so-called trade tourists going to neighbouring countries sharply decreased in 1990-1992 on international routes;

4) other factors contributing to a decrease of transportation are heavily worn road and railway transport facilities, lack of comfort, low prestige of public transport, etc.

\section{Forecasting of passenger transportation development}

Considering passenger traffic, a problem of forecasting the development of this transportation sector closely related to other areas arises [10]. In developing econometric models a researcher is usually faced with a great number of variables and a small number of observations. If only some of them are considered, the obtained data will not be correct. Therefore, one of the most suitable approaches may be the application of multiple regression analysis. In general, an assignment of forecasting is formulated as follows: let $Y=\left\{y\left(t_{i}\right)\right\}$ - onedimensional time sequence of statistical observations $t_{i+1} \div t_{i}=$ const in time moments, where $i=1, \ldots, n$. The task is to find the values for a certain period $T$ in the future, i.e. the values for the time moments $t_{j}$, where $j=n+1, \ldots, n+T$. In addition, keeping a general trend unchanged in time the inertia of the investigated process may be considered.

The equation of a time sequence for the time moment $t$ may be calculated as a sum of two components:

$$
y=f(\Theta, t)+\varepsilon(t),
$$

here, $f(\Theta, t)$ - a certain constant time function (trend); $\varepsilon(t)$ - a random function taking into account the effect of irregular factors; $\Theta$ - the parameter vector to be evaluated; $f(\Theta, t)$ characterizes major trends of the process considered, assessing their effect on the process. This means that if we find $f(\Theta, t)$ which is a constant part of the process, then $\varepsilon(t)$, the remaining part, would be a random quality. Then, it will be proved that such a process is stationary.

To determine $f(\Theta, t)$, the regression and correlation analysis is used.

If there is a relationship between the variables $t, x$, $z$, for example, $t$ - time periods, $x$ - gross national product (GNP), $z$ - national income and $y$ - number of passengers, then, if a relationship exists, we get:

$$
y^{\prime}=a t^{2}+b t+c x^{2}+d x+e z^{2}+f z+g .
$$

When the regression parameters $a, b, c, d, e, f$ and $g$ are calculated, a system of seven equations is solved.

The calculations show that national income is the most suitable parameter for making passenger traffic forecast, compared to other parameters including gross national product, monthly work payment, household income and expenditures, national wealth, production and users' cost index and variation of consumer goods and services.

In all regression equations used in forecasting, $t_{i}$ is time factor and $x_{i}$-national income factor.

The regression equation used in forecasting was of the form $i$ :

$$
\begin{aligned}
& y=(-1,0509 E-7) t_{i}^{2}-23,5586 t_{i}+ \\
& (5,3104 E-7) x_{i}^{2}+(2,9229 E-16) x_{i}+10,28,
\end{aligned}
$$

here, $t$ - time factor of transportation development trends; $x_{i}$ - national income factor; $(-1,0509 \mathrm{E}-7)=$ $-1,0509 \cdot 10^{-7}$ for this and all equations given below.

As shown in Fig 1, passenger traffic by land transport will grow up to $525 \mathrm{~m}$ people by 2010 , while by 2015 it will reach $893 \mathrm{~m}$ people, i.e. it will increase by about 1,6 and 2,6 times, respectively, compared to passenger traffic in 2001.

The following equation was used to make a forecast for transportation by bus in the city:

$$
\begin{aligned}
& y=(-8,8611 E-7) t_{i}^{2}-11,76028 t_{i}+ \\
& (2,222 E-7) x_{i}^{2}+(4,1159 E-16) x_{i}+5,24 .
\end{aligned}
$$

The regression equation for a forecast of passenger transportation by trolley-buses is as follows:

$$
\begin{aligned}
& y=(-8,5873 E-8) t_{i}^{2}-9,5879 t_{i}+ \\
& (2,4992 E-7) x_{i}^{2}+(4,1149 E-16) x_{i}+3,8 .
\end{aligned}
$$

The regression equation used to make a forecast of passenger suburban transportation by bus is expressed in the following way:

$$
\begin{aligned}
& y=(-7,4875 E-7) t_{i}^{2}-1,7123 t_{i}+ \\
& (3,2334 E-8) x_{i}^{2}+(4,8988 E-16) x_{i}+0,71 .
\end{aligned}
$$

As it can be seen in Fig 2, it is predicted that by 2010 urban passenger transportation by bus and by trolley-bus will grow up to $32 \mathrm{~m}$ and $286 \mathrm{~m}$ passengers, respectively (compared with the number of passengers transported in 2001 it will grow by 1,4 and 1,6 times, respectively), while by 2015 it will increase to $50 \mathrm{~m}$ and $443 \mathrm{~m}$ people (compared to the figures for 2001 it will grow by 2,3 and by 2,4 times, respectively). Suburban passenger transportation by bus should grow up to 220 $\mathrm{m}$ people by 2010 , and up to $344 \mathrm{~m}$ people by 2015 , implying that it will grow by 1,5 and 2,3 times, respectively, compared with the number of passengers transported in 2001. The equation used for making a forecast of long-distance passenger transportation by bus is as follows: 


$$
\begin{aligned}
& y=(-7,3627 E-8) t_{i}^{2}-0,8021 t_{i}+ \\
& (1,638 E-8) x_{i}^{2}+(4,972 E-16) x_{i}+0,346 .
\end{aligned}
$$

The regression equation used to make a forecast for international passenger transportation by bus is of the form:

$$
\begin{aligned}
& y=(-7,3163 E-8) t_{i}^{2}-0,467 t_{i}+ \\
& (8,2324 E-9) x_{i}^{2}+(5,0011 E-16) x_{i}+0,21 .
\end{aligned}
$$

As it is shown in Fig 3, it is predicted that by 2010 long-distance and international passenger transportation by bus will grow up to $16,9 \mathrm{~m}$ and $1,4 \mathrm{~m}$ people (compared to the data on 2001 it will increase by 1,44 and 1,42 times, respectively), while by 2015 it will increase to $26,4 \mathrm{~m}$ and $2,13 \mathrm{~m}$ people (compared to 2001 it will grow by 2,3 and 2,2 times, respectively).

The following regression equation was used to forecast passenger transportation by railway within the country:

$$
\begin{aligned}
& y=-7,2648 E-8 t_{i}^{2}-0,0914 t_{i}+ \\
& 1,9871 E-9 x_{i}^{2}+5,0336 E-16 x_{i}+0,0204 .
\end{aligned}
$$

For forecasting of international passengers transportations by rail road transport regression equations: 6,3 ; 1,4 were used.

$$
\begin{aligned}
& y=(-7,2611 E-8) t_{i}^{2}-0,0647 t_{i}+ \\
& (1,3253 E-9) x_{i}^{2}+(5,0357 E-16) x_{i}+0,023 .
\end{aligned}
$$

As shown in Fig 4, it is predicted that by 2010 national and international passenger transportation by railway will grow up to 7,8 $\mathrm{m}$ and $2,1 \mathrm{~m}$ people (compared to 2001 it will grow by 1,2 and 1,5 times, respectively), while by 2015 it will reach 7,8 $\mathrm{m}$ and $2,1 \mathrm{~m}$ people (compared to 2001 it will grow by 1,2 and 1,5 times, respectively), and by 2015 it will reach $12,2 \mathrm{~m}$ and 3,2 m people (compared to 2001 the increase will be by 1,9 and 2,3 times, respectively).

The above forecasts were used in working out the strategies of national road and railway transportation development.

\section{Conclusions}

1. In the period of 1992-2001 the total number of passengers transported by public land transport decreased from $1103,2 \mathrm{~m}$ to $354,1 \mathrm{~m}$ people, i.e. dropped by 3,1 times.

2. The highest decrease of the number of passengers was observed on local (suburban) bus routes and on international railway routes (by 5,6 and by 5 times, respectively), while long-distance passenger transportation by bus did not decrease much (dropping only by 1,6 times).

3. The main factors contributing to a decrease of passenger traffic are the same for road and railway transport. They are: a considerable increase of tariffs, fast growth of the number of personal cars, heavy wear of transport facilities, lack of comfort, low prestige of public transport, etc.

4. When the econometric models are developed, a small number of observations is available. Consideration of only a few of these observations would not yield the correct data. Therefore, multiple regression analysis was used to forecast major trends of passenger transportation development.

5. The calculations show that a national income parameter is most suitable for making forecasts for land transportation. It was better than other parameters, such as national income, gross national product, monthly work payment, household income and expenditures, national wealth, production and users' cost index, and the variation of consumer goods and services.

6. The forecast shows that by 2010 passenger transportation by public land transport will grow up to $575 \mathrm{~m}$ people, while by 2015 it will increase to $893 \mathrm{~m}$ people. However, the number of the transported passengers will not reach that which was recorded in 2001.

7. It is predicted that by 2010 urban passenger transportation by bus and by trolley-bus will grow up to $32 \mathrm{~m}$ and $286 \mathrm{~m}$ passengers, respectively (compared with the number of passengers transported in 2001 it will grow by 1,4 and 1,6 times, respectively), while by 2015 it will increase to $50 \mathrm{~m}$ and $443 \mathrm{~m}$ people (compared to the figures for 2001 it will grow by 2,3 and by 2,4 times, respectively). Suburban passenger transportation by bus should grow up to $220 \mathrm{~m}$ people by 2010 , and up to $344 \mathrm{~m}$ people by 2015 , implying that it will grow by 1,5 and 2,3 times, respectively, compared with the number of passengers transported in 2001. Long distance and international passenger transportation by bus will grow up to $16,9 \mathrm{~m}$ and 1,4 $\mathrm{m}$ people (compared to the data on 2001 it will increase by 1,44 and 1,42 times, respectively), while by 2015 it will increase to $26,4 \mathrm{~m}$ and 2,13 m people (compared to 2001 it will grow by 2,3 and 2,2 times, respectively). It is predicted that by 2010 national and international passenger transportation by railway will grow up to 7,8 $\mathrm{m}$ and 2,1 m people (compared to 2001 it will grow by 1,2 and 1,5 times, respectively), while by 2015 it will reach 7,8 $\mathrm{m}$ and 2,1 m people (compared to 2001 it will grow by 1,2 and 1,5 times, respectively), and by 2015 it will grow up to $12,2 \mathrm{~m}$ and 3,2 $\mathrm{m}$ people (compared to 2001 the increase will be by 1,9 and 2,3 times, respectively).

8. The forecasts made were used working out the strategies of national road and railway transportation development. 


\section{References}

1. Mazūra, M. Predictions of Major Trends of Tranportation Development. Transport, 2002, Vol XVII, No 2, p. 57-59.

2. Mazūra, M.; Fadina, O. The Reliatibility of Forecasts in Transportation. Transport, 2002, Vol XVII, No 6, p. 219222.

3. Yang, W.-H; Mathur, K.; and Ballou, R. H. Stochastic Vehicle Routing Problem with Restocking. Transportation Science, 34, 2000, p. 99-112.

4. Furnero, F.; and Vercellis, C. Synchronized Development of Production, Inventory and Distribution Schedules. Transportation Science, 33, 1999, p. 330-340.

5. Reiman, M. I.; Rubio, R.; and Wein, L. M. Hevy Traffic Analysis of the Dynamic Stochastic Inventory-Routing Problem. Transportation Science, 33, 1999, p. 361-380.
6. Miller-Hooks, E. D.; and Mahmassami, H. S. Least Expected Time Paths in Stochastic Time - Varying Transportation Networks. Transportation Science, 34, 2000, p. 198215.

7. Yang, H. System Optimum, Stochastic User Equilibrium and Optimal Link Tools. Transportation Science, 33, 1999, p. 354-360.

8. Ciancimino, A.; Inzerillo, G.; Palagi, L. A Mathematical Programming Approach for the Solution of the Railway Yield Management Problem. Transportation Science, Vol 33, 1999, p. 168-181.

9. Butkevičius, J. The Passengers Transportation (Keleivių vežimai). Vilnius, 2002. 416 p. (in Lithuanian).

10. White Book. European transport policy for 2010 - time for decision-making. European Union Commission. Brussels, 2001. 